\title{
Influence of irrigation and splitting Nitrogen fertilizer on productivity of some wheat varieties in clay soil
}

\author{
Kassab M. M., R. Kh Darwesh and M. Hefzy
}

Soils, water \& Environment, Res. Inst. (SWERI), A.R.C., Egypt

\begin{abstract}
Received: 05 Sept. 2019 / Accepted 30 Oct. 2019 / Publication date: 17 Nov. 2019
\end{abstract}
\begin{abstract}
Irrigation and fertilizers play a vital role in agriculture, so field experiments were performed in a clay soil at Sakha agricultural research station farm, Kafr El-Sheikh Governorate, during the two successive growing seasons (2017/18 and 2018/19). Experiments involving winter wheat with irrigation every $21\left(\mathrm{I}_{1}\right), 28\left(\mathrm{I}_{2}\right)$ and $35\left(\mathrm{I}_{3}\right)$ days and application of nitrogen fertilizer requirements with one, two and three doses through the season for two varieties Gemaza-11 and Misr-1. Results showed that, irrigation every 28 and 35 days were reduced the applied water by 14.0 and $20.0 \%$ less than that irrigation every 21 days. The overall mean values for wheat consumptive use can be descended in order $I_{1}>I_{2}>I_{3}$ in the two growing seasons. Gemaza-11 cultivar gave the highest value of $C U$ comparing with Misr-1. Values of productivity of irrigation water (PIW) and Water productivity (WP) were increased by decreasing the amounts of applied water, where the highest values were recorded under irrigation treatment $I_{3}$ comparing with other treatments $I_{2}$ and $I_{1}$. The highest mean values were recorded under splitting nitrogen fertilizer to three doses comparing with other treatments for Misr-1 variety. The highest mean values for grains, straw, biological yield, 1000-grain weight, plant height, number of Spikes, $\mathrm{m}^{-2}$ and Spike length, were produced with irrigation every 35 day and splitting nitrogen fertilizer to three doses for Misr-1 variety in the two seasons. So, irrigating wheat every 35 day during growing seasons and application of $\mathrm{N}$ in three doses gave the highest values of yield and yield components of Misr-1 wheat cultivar under North Nile Delta condition.
\end{abstract}

Keywords: wheat, irrigation, nitrogen fertilizer, productivity

\section{Introduction}

Wheat (Triticum aestivum L.) considers one of the most important food cereal crops grown generally in the world. Wheat (Triticum aestivum L.) is the main essential food for the $35 \%$ of the world's population. It is planted on about 100 million hectares (he. $=2.38$ fed.,) in the developing world. Global wheat production is fixed mainly in Australia, Canada, Russia, Europe, China, India, Pakistan, Turkey, Ukraine and United States, accounting for over $80 \%$ of world wheat production. Like some other crops, wheat is exhibit to many biotic and a biotic stress, which reduce yield and affect yield stability. The abiotic stresses included drought, heat, water logged, soils and soil salinity. All of these can pose serious problem for wheat farmer, especially in the less-favored growing environment. In addition to abiotic, there are also many biotic or living stresses such as diseases, insects and weeds, which can reduce wheat yields.

Water use by wheat crop primarily depends on the location, variety, planting date, and weather during the growing season. Irrigation and fertilization and their interaction are considered one of the most important factors for increasing production (Shaaban, 2006).

Water demand by wheat is variable, Doorenbos and Kassm (1979) reported that, for high yields of wheat crop water requirements are 1890 to $2730 \mathrm{~m} 3$ / fed. depending on climate and length of growing period. Sobh, (1997) at northern Delta region, reported that, irrigation water applied for wheat crop were $1560 \mathrm{~m}^{3} / \mathrm{fed}$. (5 irrigations at $320 \mathrm{~m} 3 / \mathrm{fed}$. Per irrigation) and Moursi et al., (2019) found that, the highest value of seasonal applied water was recorded with pan evaporation method at $60 \%$ allowable soil moisture depletion and the values were $2006.76 \mathrm{~m}^{3} \mathrm{fed}^{-1}$. and $2011.8 \mathrm{~m}^{3} \mathrm{fed}^{-1}$. in the first and second seasons, respectively. Meanwhile, the lowest values $1693.44 \mathrm{~m}^{3} \mathrm{fed}^{-1}$. and 1716.12 $\mathrm{m}^{3} \mathrm{fed}^{-1}$. were recorded with irrigation treatment $70 \%$ allowable soil moisture depletion in the first and second seasons, respectively.

The irrigation requirement is different from water use since water is "gained" from rainfall or "lost" from inefficiencies in irrigation water application. Irrigation efficiency, or water used divided by water applied, varies from $70-90 \%$ depending on the irrigation system (Hansen et al., 2004).

Corresponding Author: M. Hefzy, Soils, water \& Environment, Res. Inst. (SWERI), A.R.C., Egypt

E-mail:mhefzy2005@yahoo.com 
Irrigations can be scheduled using predetermined calendar dates or days between irrigations, methods that directly measure soil moisture or crop stress, or the soil water balance (checkbook) method using evapotranspiration data. Predetermined calendar dates or days between irrigations can be useful for periods irrigations under average conditions, but requires adjustment for weather conditions that vary from normal. Soil moisture and crop water stress can be measured in a variety of ways (Hansen et al., 2004) and calibrated at certain critical levels to trigger irrigation. However, these techniques are more often used in higher value crops than wheat. The soil water balance method can estimate soil moisture and impending crop stress without the investment in sensors and collection of the data they provide, but some accuracy may be lost compared to direct measurements.

El-Bably (1998) found that values of water consumptive use were $38.50,31.56$ and $24.16 \mathrm{~cm}$ for the 50, 70 and 90\% soil moisture depletion, respectively. El-Sabbagh et al. (2002) showed that seasonal water consumptive use rates were $39.70,35.72$ and $29.79 \mathrm{~cm}$ for the treatments irrigated at 45, 65 and $85 \%$ SMD, respectively. Also showed that seasonal water consumptive use increased with the decreasing irrigation period. Wheat plants extracted about 80.06 and $19.94 \%$ of its water requirements from the first upper $30 \mathrm{~cm}$ soil surface layer and the second $30 \mathrm{~cm}$ soil layer, respectively, when plants irrigated at $45 \%$ SMD. Decreasing the IR (irrigation requirements) from $100 \%$ to $50 \%$ significantly decreased most of growth characters, yield and yield attributes, while, water use efficiency was significantly increased. (Abd El Raouf et al., 2013). Abdelkhalek et al., (2015) showed that, irrigation of wheat plants 5 irrigations till harvest led to significant increase and gave the highest values of plant height $(\mathrm{cm})$, biological yield $\left(\mathrm{kg} \mathrm{fed}^{-1}\right)$, straw yield $\left(\mathrm{kg} \mathrm{fed}^{-1}\right)$, number of spikes per $\mathrm{m}^{2}$ and 1000 grain weight $(\mathrm{g})$ in both seasons compared to those irrigated 4 and 3 irrigations, respectively.

Nitrogen is a vital and essential element for all growing plants, where plants differ in their nitrogen requirements from the different sources. Nitrogen applied to the soil increased leaf area per plant to reach a maximum at the heading stage. The effect of water stress was greatest in plants provided with nitrogen at sowing where post-anthesis leaf area duration was reduced to that of plants given no nitrogen at all. (Parameswaran et al., 1981). Sobh, (1997) at northern Delta region recommended that, application of $75 \mathrm{~kg}$ nitrogen and $3.0 \mathrm{~kg} \mathrm{Zn}$ per Fadden is suitable for wheat production on clayey soil. The application of different levels of nitrogen produced significantly positive impact on yield and yield contributing characters of wheat Among the $\mathrm{N}$ doses, $140 \mathrm{~kg} \mathrm{~N}$ ha1 produced the highest grain yield. (Alam et al., 2007)

Water and nitrogen had significant collaborative compensation effects on root/shoot growth and yield traits and the effects of regulating water by nitrogen supply on root traits was larger than on shoot, while regulating nitrogen by water supply on shoot traits was larger than on root, so in actual production, it was necessary to maintain a high level of nitrogen supply in flowering stage but an appropriate level of water supply in milking stage is needed (Wang et al., 2013).

The amount of nitrogen uptake from seedling to tillering is about $45 \%$ of total, from jointing to head initiation $25 \%$, and from head initiation to grain formation $30 \%$. There are two peak periods of nitrogen uptake, at tillering and at ear-initiation stages (Mehrotra et al., 1967).

Increasing number of nitrogen fertilizer doses increased wheat yield and yield components, the increase in grain yield by increasing number of nitrogen fertilizer doses might be attributed to the supply of nitrogen in the proper stage of growth and maximizing the nitrogen utilization through minimizing losses of the applied nitrogen. (Ali, 2010 and Hefzy, 2015).

Water and crop production relationships help in selecting the strategy of best irrigation management. Improving water productivity with a view to producing more crops per unit of water used is considered as one of the important strategies for effective irrigation management. The aim of this study is to evaluate the effect of irrigation and number of nitrogen fertilizer doses for two varieties of wheat grown on clay soils.

\section{Materials and Methods}

Field experiments were conducted at Sakha Agriculture Research Station the site lies at Kafr EL Sheikh Governorate, North Middle of the Nile Delta region, during the two growing seasons 2017/18 and 2018/19 to study the effect of irrigation intervals and number of nitrogen fertilizer doses for some wheat varieties on yield and water productivity of wheat crop. 
Soil and irrigation water were analyzed at Soils, Water and Environment Research Institute (SWERI), Agricultural Research Center (ARC).

Soil particle size distribution and bulk density were determined as described by Klute (1986). Field capacity, permanent wilting point and available water characters were determined according to James (1988). Chemical characteristics of soil were determined as described by Jackson (1973) and all data are presented in Table (1).

Table 1: The mean values of soil physical and chemical properties as well soil-water constants:

\begin{tabular}{|c|c|c|c|c|c|c|c|c|c|c|}
\hline \multicolumn{11}{|c|}{ Soil physical properties } \\
\hline $\begin{array}{c}\text { Depth } \\
\text { Cm }\end{array}$ & \multicolumn{3}{|c|}{ Particle size distribution } & Texture & \multicolumn{2}{|c|}{$\begin{array}{c}\text { Bulk } \\
\text { Density, kg/m³ }\end{array}$} & F.C. $\%$ & P.W.P \% & \multicolumn{2}{|c|}{$\begin{array}{c}\text { Available } \\
\text { water } \%\end{array}$} \\
\hline $0-15$ & 19.42 & 24.10 & 56.48 & clayey & \multicolumn{2}{|c|}{1.13} & 43.25 & 21.50 & \multicolumn{2}{|c|}{21.75} \\
\hline $15-30$ & 18.55 & 23.69 & 57.76 & clayey & \multicolumn{2}{|c|}{1.23} & 42.18 & 20.55 & \multicolumn{2}{|c|}{21.63} \\
\hline $30-45$ & 18.10 & 22.85 & 59.05 & clayey & \multicolumn{2}{|c|}{1.31} & 41.08 & 20.10 & \multicolumn{2}{|c|}{20.98} \\
\hline $45-60$ & 17.85 & 22.08 & 60.07 & clayey & \multicolumn{2}{|c|}{1.32} & 39.64 & 19.85 & \multicolumn{2}{|c|}{19.79} \\
\hline & & & \multicolumn{4}{|c|}{ Soluble cations meq/l } & \multicolumn{4}{|c|}{ Soluble anions meq/l } \\
\hline Depth cm & pH & $\begin{array}{c}\text { E.C } \\
\text { dS/m }\end{array}$ & $\mathrm{Ca}^{++}$ & $\mathrm{Mg}^{++}$ & $\mathrm{Na}^{+}$ & $\mathbf{K}^{+}$ & $\mathrm{CO}_{3}=$ & $\mathrm{HCO}_{3}^{-}$ & $\mathrm{Cl}^{-}$ & $\mathrm{SO}_{4}=$ \\
\hline $0-15$ & 7.87 & 1.94 & 4.15 & 2.33 & 12.73 & 0.19 & 0.00 & 5.52 & 8.80 & 5.08 \\
\hline $15-30$ & 8.02 & 1.91 & 4.07 & 2.21 & 12.67 & 0.18 & 0.00 & 5.39 & 8.84 & 4.90 \\
\hline $30-45$ & 8.09 & 1.93 & 4.13 & 2.27 & 12.71 & 0.16 & 0.00 & 5.47 & 9.12 & 4.68 \\
\hline
\end{tabular}

*F.C.: Field capacity, P.W.P: Permanent wilting point.

For climatological data during the studied period, were recorded from Sakha Agrometeorological Station. The parameters, include; relative humidity (RH.,\%), air temperature (T., $\left.\mathrm{C}^{\circ}\right)$, wind speed $\left(\mathrm{U}_{2}, \mathrm{~km} /\right.$ day at $2 \mathrm{~m}$ height $)$ and evaporation pan $(\mathrm{Ep}, \mathrm{mm})$. as tabulated in table2.

Table 2: Some agro-meteorological data for Sakha region, ( $31^{\circ} 07^{\prime} \mathrm{N}$ Latitude, $30^{\circ} 05^{\prime} \mathrm{E}$ Longitude), during $2017 / 18$ and $2018 / 19$ season.

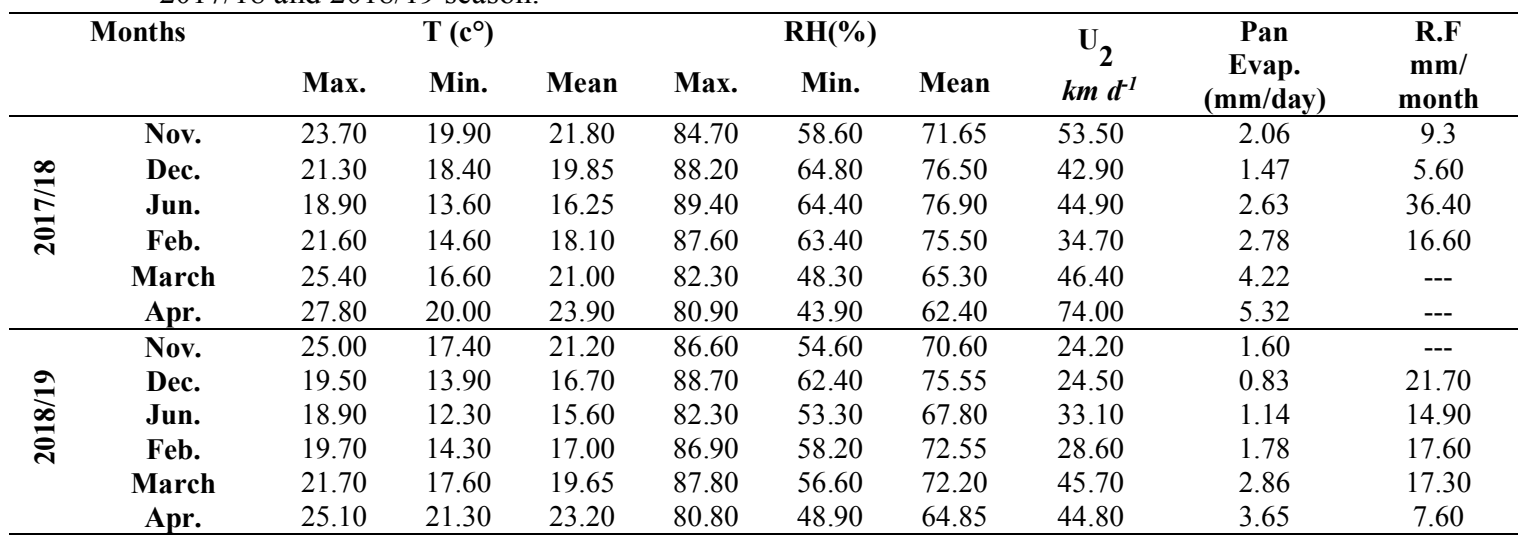

The site was preparing for sowing process. The field of the experiment area was divided into 54 plots, each plot was $52.5 \mathrm{~m}^{2}(7.5 \times 7)=1 / 80$ fed., and isolated from the other to prevent horizontal water movement. Wheat a winter crops were planted on November, 22, 2017 and November, 26, 2018 in first and second season respectively.

\section{Experimental design and treatments:}

The experimental design of current study was split-split plot design with three replications. The main plots were randomly assigned to three irrigation periods, sub main plot were also randomly assigned to three numbers of nitrogen fertilizer doses and sub-sub main plots were randomly assigned to two varieties of wheat. Which were:- 
A. Main treatments (irrigation period)

$\mathrm{I}_{1}$ : Irrigation every 21 days,

$\mathrm{I}_{2}$ : Irrigation every 28 days, and

$\mathrm{I}_{3}$ : Irrigation every 35 days.

B. Sub main treatments (number of nitrogen fertilizer doses)

$\mathrm{N}_{1}$ : Application nitrogen requirements as one dose before the first irrigation,

$\mathrm{N}_{2}$ : Application nitrogen requirements as two doses before the first and the second irrigation, and

$\mathrm{N}_{3}$ : Application nitrogen requirements as three doses. The first dose was in planting and second dose before the first irrigation and the third dose before the second irrigation.

C. Sub-sub main treatments (varieties)

$\mathrm{V}_{1}$ : Gemaza-11, and

$\mathrm{V}_{2}$ : Misr-1

Irrigation water (I.W):

Irrigation applied water (AW):

Submerged flow orifice with fixed dimension was used to convey and measure the irrigation water applied, as the following equation (Michael, 1978).

\section{Where:}

$$
\mathrm{q}=\mathrm{CA} \sqrt{ } 2 \mathrm{gh}
$$

$\mathrm{q}=$ Discharge of irrigation water $\left(\mathrm{cm}^{3} / \mathrm{s}\right)$,

$\mathrm{C}=$ Coefficient of discharge $=0.62$ (determined by experiment),

$\mathrm{A}=$ Inner cross section area of the irrigation spile $\left(\mathrm{cm}^{2}\right)$,

$\mathrm{g}=$ Gravity acceleration $\left(\mathrm{cm} / \mathrm{s}^{2}\right)$ and

$\mathrm{h}=$ Average effective head $(\mathrm{cm})$.

The volume of water delivered for each plot $\left(7 \mathrm{~m} \times 7.5 \mathrm{~m}=52.5 \mathrm{~m}^{2}\right)$ was calculated by substituting $\mathrm{Q}$ in the following equation:

\section{Where:}

$$
\mathrm{Q}=\mathrm{q} \times \mathrm{T} \times \mathrm{n}
$$

$\mathrm{Q}=$ volume of water $\mathrm{m}^{3} /$ plot,

$\mathrm{q}=$ discharge $(\mathrm{m} 3 / \mathrm{min})$,

$\mathrm{T}=$ total irrigation time $(\mathrm{min})$ and

$\mathrm{n}=$ number of spiles tube per each plot.

\section{Water consumptive use, $\mathrm{cm}$ :}

Water consumptive use was calculated as soil moisture depletion (SMD) according to Hansen et al. (1979).

Where:

$$
C u=S M D=\sum_{i=1}^{i=N} \frac{\theta_{2}-\theta_{1}}{100} * D b i * D i * A
$$

$\mathrm{CU}=$ Water consumptive use in the effective root zone $(60 \mathrm{~cm}), \mathrm{cm}$,

$\Theta_{2}=$ Gravimetric soil moisture percentage 48 hours after irrigation,

$\Theta_{1}=$ Gravimetric soil moisture percentage before irrigation,

$\mathrm{Dbi}=$ soil bulk density $\left(\mathrm{Mg} \mathrm{m}^{-3}\right)$ for the given depth,

$\mathrm{D}_{\mathrm{i}}=$ soil layer depth $(20 \mathrm{~cm})$,

$\mathrm{i}=$ number of soil layers each $(15 \mathrm{~cm})$ depth and

$\mathrm{A}=$ irrigation area (fed.,)

\section{Crop- water relations:}

\section{Water productivity (WP):}

Water productivity is generally outlined as crop yield per cubic metre of water consumption. It was calculated according to Ali et al. (2007) 


$$
W P=\frac{G Y}{E T}
$$

Where:

$$
\begin{aligned}
& \mathrm{WP}=\text { water productivity }\left(\mathrm{kg} \mathrm{m}^{-3}\right) \\
& \mathrm{GY}=\text { yield }\left(\mathrm{kg} \mathrm{fed}^{-1}\right) \text { and } \\
& \text { ET }=\text { Total water consumption of the growing season }\left(\mathrm{m}^{3} \mathrm{fed}^{-1}\right) .
\end{aligned}
$$

\section{Productivity of irrigation water (PIW):}

Productivity of irrigation water (PIW) was estimated according to (Ali et al., 2007).

$$
P I W=\frac{G Y}{A W}
$$

Where:

PIW = productivity of irrigation water $\left(\mathrm{kg} \mathrm{m}^{-3}\right)$,

Gy $=$ yield $\mathrm{kg} /$ fed and

$\mathrm{AW}=$ applied water $\left(\mathrm{m}^{3} /\right.$ fed.). (Irrigation water + effective rainfall)

Note: effect rainfall $=$ rianfall $* 0.7$ (Novica, 1979)

\section{Consumptive use efficiency (Ecu\%):}

The consumptive use efficiency (Ecu) was calculated as described by Doornbos and Pruitt (1977) as follows:

$$
E c u=\frac{\mathrm{ETc}}{\mathrm{Wa}} \times 100
$$

Where:

$$
\begin{aligned}
& \text { Ecu }=\text { Consumptive use efficiency } \% \\
& \text { ETc }=\text { Total evapotranspiration } \simeq \text { consumptive use }\left(\mathrm{m}^{3} \mathrm{fed}^{-1}\right) . \\
& \text { Wa }=\text { Water applied to the field }\left(\mathrm{m}^{3} \mathrm{fed}^{-1}\right) .
\end{aligned}
$$

\section{Statistical analysis:}

All data were statistically explored according to the technique of analysis of variance (ANOVA) as published by Gomez and Gomez (1984). Means of the treatment were compared by the least significant difference (LSD) at 5\% level and $1 \%$ level of significance which developed by Waller and Duncan (1979).

\section{Results and Discussion}

\section{Applied irrigation water}

Wheat considers a winter crops so, applied water for it consists of two main components delivered to the field plot in addictions to the effective rainfall. Presented data in Table 3 showed irrigation every 28 and 35 days recorded least amounts of applied water where the overall mean 15.01 and $22.58 \%$ for $\mathrm{V}_{1}$ (Gemaza-11) and 16.13 and $22.70 \%$ for $\mathrm{V}_{2}$ (Misr 1) comparing with irrigation every 21 days. These findings were in agreement with that obtained by Ashraf et al. (2001) they showed that irrigation periods saved water up to $50 \%$ compared with farmers' practices.

For nitrogen doses $\left(\mathrm{N}_{1}, \mathrm{~N}_{2}\right.$ and $\left.\mathrm{N}_{3}\right)$ the values for $\mathrm{V}_{2}$ (Misr 1) exhibited lower values comprised 6.56, 6.11 and $4.10 \%$ in $2017 / 18$ season and in 2018/19 season the reduction reached $5.64,3.50$ and $5.22 \%$, as compared with $\mathrm{V}_{1}$ (Gemaza-11) regardless irrigation periods, applied irrigation water. In connection, These results were in the same line with those obtained by Moursi and Darwesh (2014)

Data in Table 3 revealed that the highest value of applied irrigation water was noticed due to convenient irrigation method the irrigation every 21 days and applied nitrogen in three doses for Gemaza-11, and such trend was true in the two seasons of study and overall mean as well. On the contrary, the lowest value of applied irrigation water was recorded as the quantity of applied 
irrigation water was determined based on irrigation every 35 days and applied nitrogen in one dose for Misr-1, and such findings were noticed in 2017/18 and 2018/19 seasons besides the overall mean.

Table 3: Seasonal applied irrigation water $\left(\mathrm{m}^{3} \mathrm{fed} \cdot{ }^{-1}\right)$ in the two growing seasons.

\begin{tabular}{|c|c|c|c|c|c|c|c|c|c|c|}
\hline \multirow{2}{*}{ Varieties } & \multirow{2}{*}{$\begin{array}{l}\text { Irrigation } \\
\text { periods }\end{array}$} & \multicolumn{8}{|c|}{ Seasonal water applied, $\mathbf{m}^{3}$ fed $^{-1}$} & \multirow{3}{*}{$\begin{array}{c}\text { Overall } \\
\text { mean }\end{array}$} \\
\hline & & \multicolumn{4}{|c|}{ 2017/18 } & \multicolumn{4}{|c|}{$\begin{array}{r}2018 / 19 \\
\end{array}$} & \\
\hline \multicolumn{2}{|c|}{ Fertilizers } & $\mathbf{N}_{1}$ & $\mathbf{N}_{2}$ & $\mathbf{N}_{3}$ & Mean & $\mathbf{N}_{1}$ & $\mathbf{N}_{2}$ & $\mathbf{N}_{3}$ & Mean & \\
\hline \multirow{3}{*}{$\mathbf{V}_{\mathbf{1}}$} & $\mathbf{I}_{1}$ & 2440.00 & 2550.55 & 2611.52 & 2534.02 & 2290.00 & 2340.90 & 2500.5 & 2377.00 & 2455.51 \\
\hline & $\mathbf{I}_{2}$ & 2080.00 & 2120.00 & 2240.00 & 2146.66 & 1940.00 & 1990.5 & 2150.20 & 2026.90 & 2086.78 \\
\hline & $\mathbf{I}_{3}$ & 1860.20 & 1950.50 & 2010.25 & 1940.32 & 1801.50 & 1845.50 & 1940.20 & 1862.40 & 1901.36 \\
\hline \multicolumn{2}{|c|}{ Mean $V_{1}$} & 2126.73 & 2207.02 & 2287.26 & 2207.00 & 2010.5 & 2058.97 & 2196.97 & 2088.81 & 2147.91 \\
\hline \multirow{3}{*}{$\mathbf{V}_{2}$} & $I_{1}$ & 2300.50 & 2390.25 & 2490.25 & 2393.75 & 2180.50 & 2310.00 & 2340.50 & 2277.00 & 2335.38 \\
\hline & $\mathbf{I}_{2}$ & 1880.25 & 2005.50 & 2150.00 & 2011.93 & 1790.50 & 1910.50 & 2015.25 & 1905.42 & 1958.68 \\
\hline & $\mathbf{I}_{3}$ & 1780.50 & 1820.50 & 1940.50 & 1847.17 & 1720.02 & 1740.50 & 1890.20 & 1783.57 & 1815.30 \\
\hline \multirow{2}{*}{\multicolumn{2}{|c|}{$\begin{array}{l}\text { Mean } V_{2} \\
\text { Mean V }\end{array}$}} & 1987.08 & 2072.08 & 2193.58 & 2084.25 & 1897.02 & 1987.00 & 2081.98 & 1988.55 & 2036.40 \\
\hline & & 2056.91 & 2139.55 & 2240.40 & 2145.63 & 1953.76 & 2022.98 & 2139.48 & 2038.68 & 2092.16 \\
\hline
\end{tabular}

Presented data in Table (4) and figure (1) obviously demonstrate that the mean values of wheat consumptive use were affected by irrigation treatments, nitrogen doses and wheat varieties in the two growing seasons. The highest mean value for wheat consumptive use was recorded under irrigation treatment $I_{1}$ and the highest overall mean value $47.78,45.94 \mathrm{~cm}$ in the first and second growing seasons, respectively. On the other hand, the lowest overall mean value during the two growing seasons was recorded under irrigation treatment $\mathrm{I}_{3}$ and the corresponding values are 36.48 and 34.79 $\mathrm{cm}$. The overall mean values for wheat consumptive use can be descended in order $\mathrm{I}_{1}>\mathrm{I}_{2}>\mathrm{I}_{3}$ in the two growing seasons. Increasing the mean values of wheat consumptive use under irrigation treatment $\mathrm{I}_{1}$ (which received a large number of watering) comparing with other irrigation periods $\mathrm{I}_{2}$ and $\mathrm{I}_{3}$ (which exposed to water stress through the growing season by receiving low number of waterings might be assign to increasing number of irrigations under the conditions of this treatment because of decreasing irrigation intervals. So, increasing applied irrigation water and hence increasing consumptive use values. These results coincided with those obtained by Ouda et al., (2010)

Concerning the effect of nitrogen doses, the highest overall mean values for wheat consumptive use were recorded under splitting nitrogen into three equal doses $\mathrm{N}_{3}$ in comparison with other two nitrogen doses. Increasing the mean values of wheat consumptive use under $\mathrm{N}_{3}$ in the two growing season might be assign to increasing availability of soil nutrients and hence, increasing uptake rate of these nutrients.

Therefore, forming healthy plants with thick vegetative cover. Consequently increasing water consumed by plants to compensate the large water losses by evaporation as a result of increasing exposed surface area for plants to the sunlight under the conditions of splitting nitrogen into three equal doses $\left(\mathrm{N}_{3}\right)$. These results the same line with those obtained by Moursi and Darwesh (2014) and Raj raj Pal Meena et al., (2019).

Table 4: Effect of irrigation intervals, nitrogen doses and wheat varieties on consumptive use, $\mathrm{cm} \mathrm{fed}^{-1}$ in the two growing seasons

\begin{tabular}{|c|c|c|c|c|c|c|c|c|c|c|}
\hline \multirow{2}{*}{ Varieties } & \multirow{2}{*}{$\begin{array}{c}\text { Irrigation } \\
\text { periods }\end{array}$} & \multicolumn{9}{|c|}{ Seasonal Consumptive Use, $\mathrm{cm}$ fed $^{-1}$} \\
\hline & & \multicolumn{4}{|c|}{$2017 / 18$} & \multicolumn{4}{|c|}{$2018 / 19$} & \multirow[b]{2}{*}{$\begin{array}{c}\text { Overall } \\
\text { mean }\end{array}$} \\
\hline \multicolumn{2}{|c|}{ Fertilizers } & $\mathbf{N}_{1}$ & $\mathbf{N}_{2}$ & $\mathbf{N 3}$ & Mean I & $\mathbf{N}_{1}$ & $\mathbf{N}_{2}$ & $\mathbf{N 3}$ & Mean I & \\
\hline \multirow{3}{*}{$\mathbf{V}_{1}$} & $\mathbf{I}_{1}$ & 44.43 & 47.50 & 49.60 & 47.19 & 46.19 & 48.42 & 50.50 & 48.37 & 47.78 \\
\hline & $\mathbf{I}_{2}$ & 39.56 & 39.06 & 42.69 & 40.44 & 38.83 & 40.93 & 43.82 & 41.19 & 40.82 \\
\hline & $\mathbf{I}_{3}$ & 33.67 & 35.04 & 36.28 & 34.99 & 36.92 & 37.65 & 39.34 & 37.97 & 36.48 \\
\hline \multirow{3}{*}{$\mathbf{V}_{2}$} & $I_{1}$ & 43.38 & 44.85 & 48.40 & 45.54 & 43.85 & 47.10 & 48.10 & 46.35 & 45.94 \\
\hline & $\mathbf{I}_{2}$ & 35.65 & 37.25 & 40.60 & 37.83 & 36.30 & 39.30 & 40.45 & 38.68 & 38.25 \\
\hline & $\mathrm{I}_{3}$ & 32.50 & 34.35 & 35.80 & 34.21 & 34.19 & 34.69 & 37.28 & 35.38 & 34.79 \\
\hline \multirow{2}{*}{\multicolumn{2}{|c|}{$\begin{array}{l}\text { Mean } V_{2} \\
\text { Mean V }\end{array}$}} & 37.18 & 38.82 & 41.6 & 39.20 & 38.11 & 40.36 & 41.94 & 40.14 & 39.67 \\
\hline & & 38.2 & 39.675 & 42.23 & 40.03 & 39.38 & 41.35 & 43.25 & 41.32 & 40.68 \\
\hline
\end{tabular}




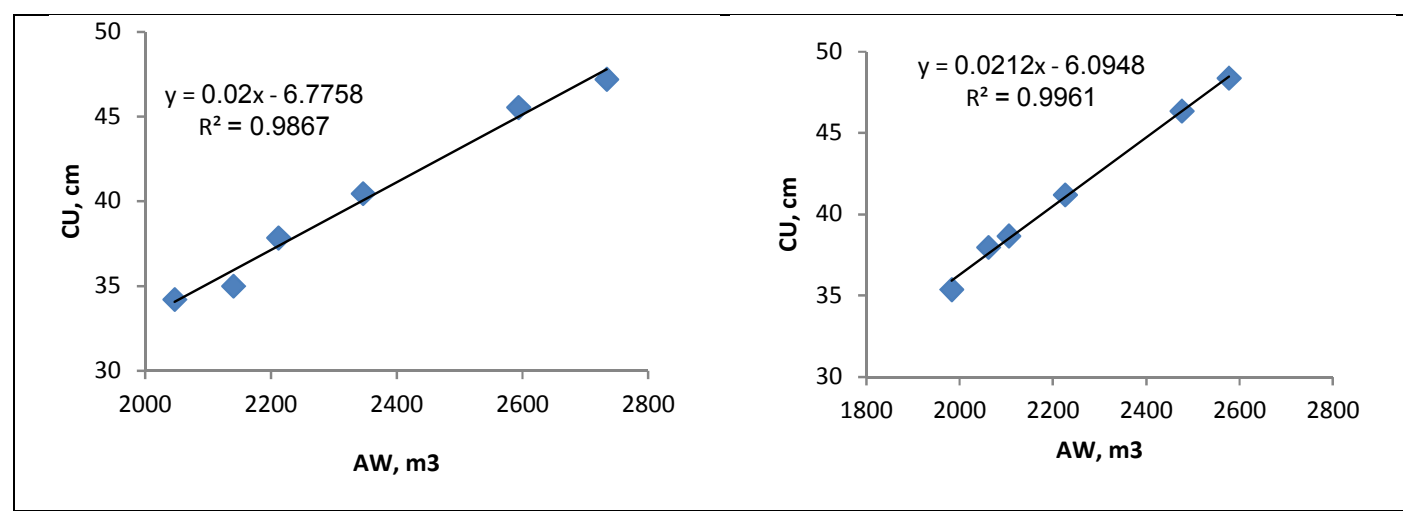

Fig 1: Correlation between applied irrigation water, $\mathrm{cm}$ under overall nitrogen doses and wheat varieties on consumptive use, $\mathrm{cm}$ (plant water consumption) in the two growing seasons.

Meaningfully, irrigating the wheat cultivar Gemaza-11 gave the highest value of CU comparing with the Misr-1 cultivar under overall irrigation treatments and nitrogen doses.

\section{Crop water efficiencies}

\section{Productivity of irrigation water (PIW)}

Presented data in Table (5) showed that, productivity of irrigation water (PIW) was affected by irrigation water periods; the values were increased under increasing water stress conditions in the two growing seasons. Under overall nitrogen doses and wheat varieties, the highest and lowest values of PIW were recorded under $I_{3}$ and $I_{1}$ treatments, respectively, in two seasons. Concerning with the effect of irrigation intervals the highest mean values for WIP under irrigation treatment $\left(\mathrm{I}_{3}\right)$ in the two growing seasons are 1.66 and $1.89 \mathrm{Kg} / \mathrm{m}^{3}$ for Gemaza-11 and Misr-1 respectively. On the contrary, the lowest mean values were recorded under irrigation treatment $I_{1}$ and the mean values are 1.24 and $1.40 \mathrm{Kg} / \mathrm{m}^{3}$ for Gemaza-11 and Misr-1 respectively. Generally, the mean vales for PIW can be descended in order $I_{3}>I_{2}>I_{1}$ in the two growing seasons. These finding were in general agreement with the observations that increasing water level led to decrease WUE Abd El-Hay (2008) and Shah et al., (2006)

Regarding, the effect of nitrogen doses, the highest mean values were recorded under nitrogen splitting into three equal doses $\left(\mathrm{N}_{3}\right)$, under irrigation treatment $\mathrm{I}_{3}$ in the two growing seasons.

Results presented in Table 5 showed also that values of WIP increased with Misr-1 with 12$13 \%$ compared to Gemaza-11 in the two growing season. Generally, the highest mean values for (PIW) were recorded under $\mathrm{I}_{3} \mathrm{~N}_{3} \mathrm{~V}_{2}$ treatment in the two growing season.

\section{Water productivity}

Water productivity was computed to evaluate the treatments for maximum yield per unit of consumed water in the field. In this case, the greatest WP values for wheat were observed in $\mathrm{I}_{3}(1.95$ and $\left.1.95 \mathrm{~kg} \mathrm{~m}^{-3}\right)$, followed by $\mathrm{I}_{2}\left(1.87\right.$ and $\left.1.80 \mathrm{~kg} \mathrm{~m}^{-3}\right)$, and $\mathrm{I}_{1}\left(1.52\right.$ and $\left.1.46 \mathrm{~kg} \mathrm{~m}^{-3}\right)$ for Gemaza-11 in the first and second seasons respectively. On the other hand for Misr-1 the corresponding values under irrigation treatments $I_{3}\left(2.41\right.$ and $\left.2.28 \mathrm{~kg} \mathrm{~m}^{-3}\right)$, followed by $I_{2}\left(2.16\right.$ and $\left.2.07 \mathrm{~kg} \mathrm{~m}^{-3}\right)$, and $\mathrm{I}_{1}$ $\left(1.74\right.$ and $\left.1.66 \mathrm{~kg} \mathrm{~m}^{-3}\right)$ in the first and second seasons, respectively. Slight increase in WP in $\mathrm{I}_{3}$ than in $\mathrm{I}_{2}$ and $\mathrm{I}_{1}$ were associated with a lower amount of irrigation water than the corresponding increase in seed yield. These results are in a great harmony with those obtained by Abdelkhalek et al. (2015), they reported that the irrigation treatments ( 3 events) gave the highest values for grain yield.

Regarding, the effect of nitrogen doses, the highest mean values were recorded under nitrogen splitting into three equal doses $\left(\mathrm{N}_{3}\right)$, under irrigation treatment $\mathrm{I}_{3}$ in the two growing seasons.

Results presented in Table 6 show also that values of PW increased with Misr-1 by $12-13 \%$ compared to Gemaza-11 in the two growing season. Generally, the highest mean values for (WP) were recorded under $\mathrm{I}_{3} \mathrm{~N}_{3} \mathrm{~V}_{2}$ in the two growing season. 
Table 5: Effect of irrigation intervals, nitrogen doses and wheat varieties on seasonal productivity of irrigation water $\left(\mathrm{kgm}^{-3}\right.$ in the two growing seasons.

\begin{tabular}{|c|c|c|c|c|c|c|c|c|c|c|}
\hline \multirow{2}{*}{ Varieties } & \multirow{2}{*}{$\begin{array}{c}\text { Irrigation } \\
\text { periods }\end{array}$} & \multicolumn{9}{|c|}{ Seasonal Productivity of irrigation water $\mathrm{kg} \mathrm{m}^{3}$} \\
\hline & & \multicolumn{4}{|c|}{$2017 / 18$} & \multicolumn{4}{|c|}{$2018 / 19$} & \multirow[b]{2}{*}{$\begin{array}{c}\text { Overal } \\
\text { mean }\end{array}$} \\
\hline \multicolumn{2}{|c|}{ Fertilizers } & $\mathbf{N}_{1}$ & $\mathbf{N}_{2}$ & $\mathbf{N}_{3}$ & Mean I & $\mathbf{N}_{1}$ & $\mathbf{N}_{2}$ & $\mathbf{N}_{3}$ & Mean I & \\
\hline \multirow{3}{*}{$\mathbf{V}_{1}$} & $\mathbf{I}_{1}$ & 1.24 & 1.23 & 1.21 & 1.23 & 1.26 & 1.27 & 1.23 & 1.25 & 1.24 \\
\hline & $\mathbf{I}_{2}$ & 1.48 & 1.48 & 1.48 & 1.48 & 1.55 & 1.55 & 1.51 & 1.54 & 1.51 \\
\hline & $\mathbf{I}_{3}$ & 1.67 & 1.63 & 1.66 & 1.65 & 1.67 & 1.66 & 1.68 & 1.67 & 1.66 \\
\hline \multicolumn{2}{|c|}{ Mean $V_{1}$} & 1.46 & 1.46 & 1.45 & 1.45 & 1.48 & 1.49 & 1.47 & 1.48 & 1.47 \\
\hline \multirow{3}{*}{$\mathbf{V}_{2}$} & $I_{1}$ & 1.36 & 1.41 & 1.40 & 1.39 & 1.41 & 1.42 & 1.44 & 1.42 & 1.40 \\
\hline & $\mathbf{I}_{2}$ & 1.73 & 1.70 & 1.70 & 1.71 & 1.77 & 1.78 & 1.76 & 1.77 & 1.74 \\
\hline & $\mathbf{I}_{3}$ & 1.84. & 1.91 & 1.87 & 1.88 & 1.85 & 1.97 & 1.89 & 1.90 & 1.89 \\
\hline \multirow{2}{*}{\multicolumn{2}{|c|}{$\begin{array}{c}\text { Mean } V_{2} \\
\text { Mean V }\end{array}$}} & 1.64 & 1.66 & 1.64 & 1.66 & 1.67 & 1.71 & 1.70 & 1.69 & 1.68 \\
\hline & & 1.55 & 1.56 & 1.54 & 1.55 & 1.57 & 1.60 & 1.59 & 1.59 & 1.57 \\
\hline \multicolumn{2}{|c|}{ LSD } & & 0.037 & & -- & & 0.043 & & -- & -- \\
\hline \multirow{7}{*}{$F$ test } & I & & $* *$ & & -- & & $* *$ & & -- & -- \\
\hline & V & & $*$ & & -- & & $*$ & & -- & -- \\
\hline & $\mathbf{N}$ & & $* *$ & & -- & & $* *$ & & -- & -- \\
\hline & $I^{*} \mathbf{V}$ & & $* *$ & & -- & & $* *$ & & -- & -- \\
\hline & $\mathbf{I} * \mathbf{N}$ & & $*$ & & -- & & $*$ & & -- & -- \\
\hline & $\mathbf{N} * \mathbf{V}$ & & $*$ & & -- & & $*$ & & -- & -- \\
\hline & $I * N * V$ & & $* *$ & & -- & & $* *$ & & -- & -- \\
\hline
\end{tabular}
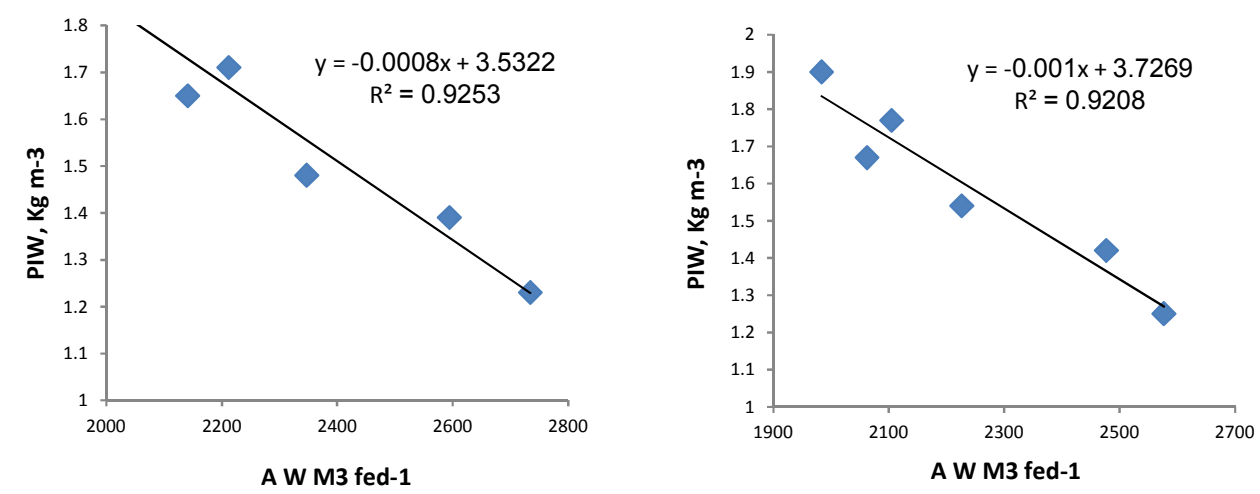

Fig 2: Correlation between applied irrigation water, $\mathrm{m}^{3} \mathrm{fed}^{-1}$ under overall nitrogen doses and wheat varieties on productivity of irrigation water $\mathrm{kg} \mathrm{m}^{-3}$ in the two growing seasons.

Table 6: Effect of irrigation intervals, nitrogen doses and wheat varieties on seasonal water productivity $\left(\mathrm{kgm}^{-3}\right)$ in the two growing seasons.

\begin{tabular}{|c|c|c|c|c|c|c|c|c|c|c|}
\hline Varieties & $\begin{array}{c}\text { Irrigation } \\
\text { periods }\end{array}$ & \multicolumn{9}{|c|}{ Seasonal water Productivity $\mathrm{kg} \mathrm{m}^{3}$} \\
\hline \multicolumn{2}{|c|}{ Fertilizers } & $\mathbf{N}_{1}$ & $\mathbf{N}_{2}$ & $\mathbf{N}_{3}$ & Mean I & $\mathbf{N}_{1}$ & $\mathbf{N}_{2}$ & $\mathbf{N}_{3}$ & Mean I & $\begin{array}{c}\text { Overall } \\
\text { mean }\end{array}$ \\
\hline \multirow{2}{*}{$\mathbf{V}_{1}$} & $\mathbf{I}_{2}$ & 1.86 & 1.91 & 1.85 & 1.87 & 1.86 & 1.80 & 1.76 & 1.80 & 1.83 \\
\hline & $\mathbf{I}_{3}$ & 2.20 & 2.16 & 2.19 & 2.18 & 1.95 & 1.94 & 1.97 & 1.95 & 2.06 \\
\hline \multicolumn{2}{|c|}{ Mean $V_{1}$} & 1.78 & 1.85 & 1.81 & 1.81 & 1.76 & 1.73 & 1.72 & 1.73 & 1.78 \\
\hline \multirow[t]{2}{*}{$\mathbf{V}_{2}$} & $\mathbf{I}_{2}$ & 2.17 & 2.18 & 2.14 & 2.16 & 2.07 & 2.07 & 2.09 & 2.07 & 2.11 \\
\hline & $\mathbf{I}_{3}$ & 2.40 & 2.41 & 2.42 & 2.41 & 2.22 & 2.36 & 2.28 & 2.28 & 2.34 \\
\hline \multirow{2}{*}{\multicolumn{2}{|c|}{$\begin{array}{c}\text { Mean V }{ }_{2} \\
\text { Mean V }\end{array}$}} & 2.06 & 2.09 & 2.06 & 2.07 & 1.98 & 2.03 & 2.01 & 2.00 & 2.03 \\
\hline & & 1.96 & 1.97 & 1.93 & 1.95 & 1.87 & 1.88 & 1.87 & 1.87 & 1.91 \\
\hline \multicolumn{2}{|c|}{ LSD } & & 0.033 & & -- & & 0.052 & & -- & -- \\
\hline \multirow{3}{*}{$F$ test } & I & & $* *$ & & -- & & $* * *$ & & -- & -- \\
\hline & $\mathbf{N} * \mathbf{V}$ & & $*$ & & -- & & $*$ & & -- & -- \\
\hline & $I^{*} \mathbf{N} * \mathbf{V}$ & & * & & -- & & $*$ & & -- & -- \\
\hline
\end{tabular}




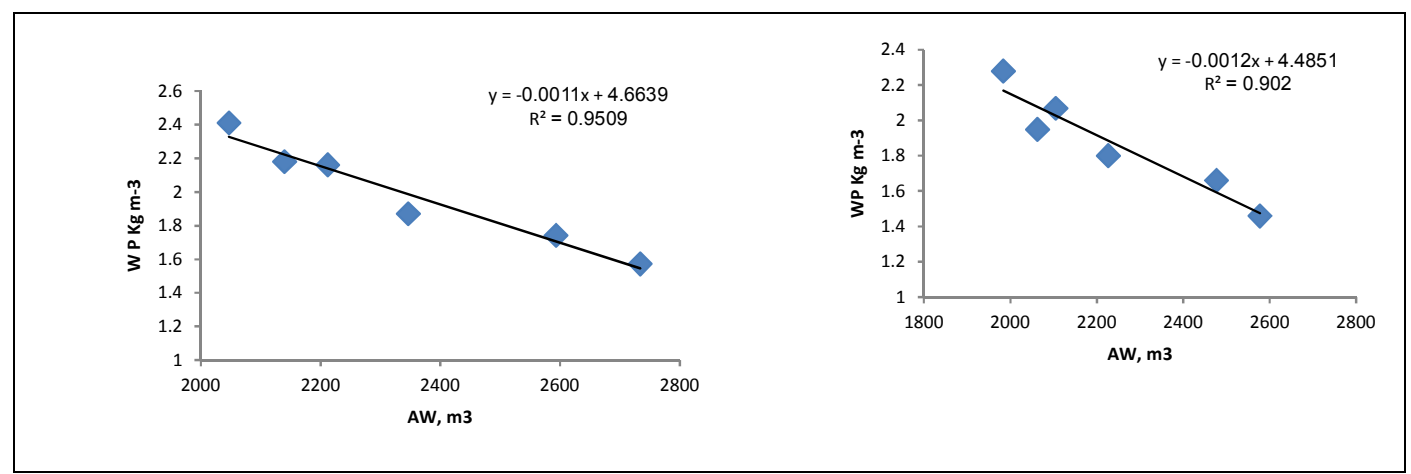

Fig 3: Correlation between applied irrigation water, $\mathrm{m}^{3} \mathrm{fed}^{-1}$ under overall nitrogen doses and wheat varieties on water productivity $\mathrm{kg} \mathrm{m}^{-3}$ in the two growing seasons.

\section{Yield and its components:}

\section{Biological yield kg fed., ${ }^{-1}$}

Biological yield means the sum of the two components of grain and straw yield. Data in Table (7) obviously showed that there is a high significant difference in the mean values of biological yield for the studied irrigation periods, wheat cultivars and nitrogen doses, where the highest mean values were produced from irrigation every 35 day with three nitrogen doses for Misr-1 variety in the two seasons. These results were agreement with Moursi et al., (2019)

The interaction between irrigation intervals shows no significant effect with nitrogen doses, variety and both together. But variety showed a significant effect with nitrogen doses.

Table 7: Effect of irrigation intervals, nitrogen doses and wheat varieties on seasonal biological yield $\left(\mathrm{kg} \mathrm{fed}^{-1}\right)$ in the two growing seasons.

\begin{tabular}{|c|c|c|c|c|c|c|c|c|c|c|}
\hline \multirow{2}{*}{ Varieties } & \multirow{2}{*}{$\begin{array}{c}\text { Irrigation } \\
\text { periods }\end{array}$} & \multicolumn{9}{|c|}{ Seasonal biological yield $\mathrm{kg} \mathrm{fed}^{-1}$} \\
\hline & & \multicolumn{3}{|c|}{$2017 / 18$} & \multicolumn{5}{|c|}{$2018 / 19$} & \multirow[b]{2}{*}{$\begin{array}{c}\text { Overall } \\
\text { mean }\end{array}$} \\
\hline \multicolumn{2}{|c|}{ Fertilizers } & $\mathbf{N}_{1}$ & $\mathbf{N}_{2}$ & $\mathbf{N}_{3}$ & Mean I & $\mathbf{N}_{1}$ & $\mathbf{N}_{2}$ & $\mathbf{N}_{3}$ & Mean I & \\
\hline \multirow{2}{*}{$\mathbf{V}_{1}$} & $\mathbf{I}_{2}$ & 8836.7 & 9128.2 & 9167.7 & 9044.2 & 8683.3 & 8980.0 & 8975.0 & 8879.4 & 8961.8 \\
\hline & $\mathbf{I}_{3}$ & 8903.3 & 9200.0 & 9235.0 & 9122.8 & 8793.3 & 9095.0 & 9110.0 & 8999.4 & 9056.1 \\
\hline \multirow[t]{2}{*}{$\mathbf{V}_{2}$} & $\mathbf{I}_{2}$ & 8720.0 & 8243.3 & 9084.3 & 8682.3 & 8583.3 & 8098.3 & 8896.7 & 8526.1 & 8604.3 \\
\hline & $\mathbf{I}_{3}$ & 8813.3 & 8300.0 & 9185.0 & 8766.1 & 8690.0 & 8160.0 & 9047.7 & 8432.6 & 8699.3 \\
\hline \multirow{2}{*}{\multicolumn{2}{|c|}{$\begin{array}{c}\text { Mean } V_{2} \\
\text { Mean V }\end{array}$}} & 8694.4 & 8198.9 & 9075.3 & 8714.3 & 8540.0 & 8042.8 & 8904.2 & 8495.7 & 8575.9 \\
\hline & & 8745.6 & 8644.2 & 9106.5 & 8832.1 & 8588.3 & 8491.1 & 8931.3 & 8751.1 & 8762.7 \\
\hline \multicolumn{2}{|c|}{ LSD } & & 371.77 & & -- & & 379.27 & & -- & -- \\
\hline \multirow[t]{4}{*}{ F test } & $\mathbf{I} * \mathbf{V}$ & & NS & & -- & & NS & & -- & -- \\
\hline & $\mathbf{I} * \mathbf{N}$ & & NS & & -- & & NS & & -- & -- \\
\hline & $\mathbf{N} * \mathbf{V}$ & & $* *$ & & -- & & $*$ & & -- & -- \\
\hline & $I * N * V$ & & NS & & -- & & NS & & -- & -- \\
\hline
\end{tabular}

\section{Grain yield kg fed ${ }^{-1}$}

Results showed that also grain yield $\mathrm{kg} \mathrm{fed}^{-1}$ was significantly affected by irrigation periods, variety and nitrogen doses as showed in (Table 8). The data indicated that maximum grain yield $\mathrm{kg}$ fed $^{-1}$ was produced with Misr-1 compared with Gemaza-11 in the two growing seasons. Among irrigation periods, maximum grain yield $\mathrm{kg} \mathrm{fed}^{-1}$ was noted when wheat irrigated every 35 days $\left(\mathrm{I}_{3}\right)$ with values 3167.31 and $3433.14 \mathrm{~kg} \mathrm{fed}^{-1}$ for Gemaza-11 and Misr-1 overall mean the two growing seasons, respectively. Nitrogen doses revealed maximum grain yield $\mathrm{kg} \mathrm{fed}^{-1}$ under application $\mathrm{N}$ in 
three doses $\left(\mathrm{N}_{3}\right)$ in the two growing seasons under overall irrigation periods for the two variety. These results are in a great harmony with those obtained by Abdelkhalek et al. (2015), they reported that the irrigation treatments ( 5 events) gave the highest values for grain yield.

Generally, the mean values of wheat grain yield can be descended in order $I_{3}>I_{2}>I_{1}$. Increasing the mean values of wheat grain yield under irrigation treatment $I_{3}$ which received amount of irrigation water applied in a morally good time therefore, moderate uptake rate of the nutrients this improves and increases root yield under the conditions of this treatment comparing with other treatments $I_{2}$ and $\mathrm{I}_{1}$.

The interaction between irrigation intervals, varieties and nitrogen doses showed no significant effect on grain yield, kg fed., ${ }^{-1}$ in the two growing seasons except the interaction between variety and nitrogen doses in the second season.

Table 8: Effect of irrigation intervals, nitrogen doses and wheat varieties on seasonal grain yield $\left(\mathrm{kg} \mathrm{fed}^{-1}\right)$ in the two growing seasons.

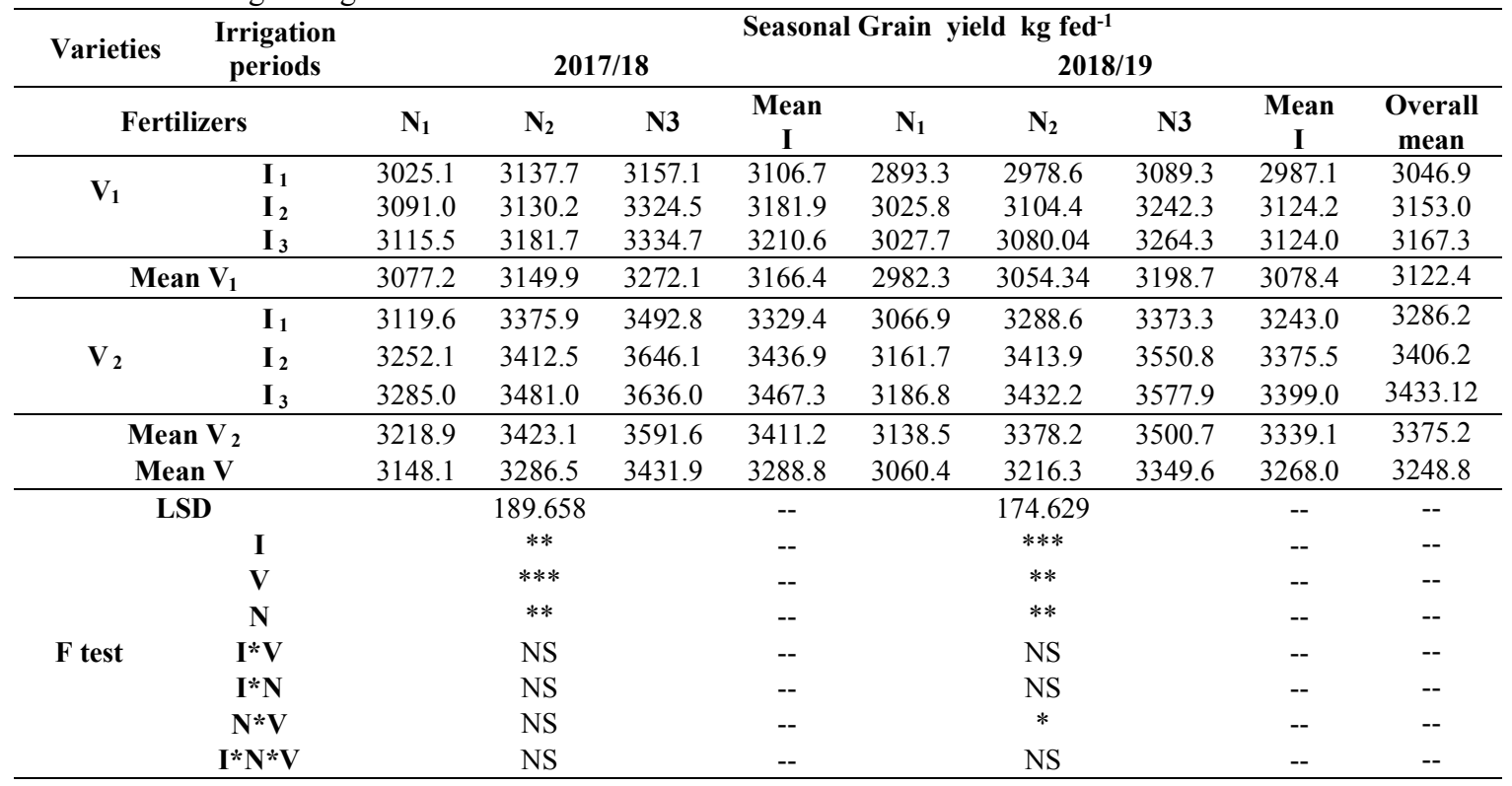

\section{Straw yield kg fed., ${ }^{-1}$}

Tabulated data in Table (9) illustrated that wheat straw yield was highly affected by studied irrigation periods in the two growing seasons where the highest mean values were recorded from irrigation every 35 days $\mathrm{I}_{3}$ and the mean values are 5887.15 and $5881.51 \mathrm{~kg}$ fed., ${ }^{-1}$ for Gemaza- 11 and 505.45 and 5269.45 for Misr-1 in the first and second growing seasons, respectively.

For wheat cultivars in the two growing seasons Gemaza-11 gave highest mean values of straw yield. Increasing the mean values of straw yield under Gemaza-11 might be due to forming strong and condensed vegetative cover for plants in comparison with the other cultivar and this also might be due to morphological characteristics for each cultivar.

Concerning nitrogen doses, straw yield increased where the highest values in three doses application $\mathrm{N}_{3}$ in overall irrigation periods and varieties in the growing seasons. This might due to the distribution of nitrogen doses into three doses increases the absorbance and the loss of it, increases the total sum associated with significantly absorption of the nitrogen element in the plant for a longer period and hence strong straw yield. These results the same line with those obtained by Moursi and Darwesh (2014).

The interaction between irrigation intervals, variety and nitrogen doses showed not significant effect on straw yield, $\mathrm{kg}$ fed., ${ }^{-1}$ in the two growing seasons except the interaction between variety and nitrogen doses in the two seasons. 
Table 9: Effect of irrigation intervals, nitrogen doses and wheat varieties on seasonal straw yield $\left(\mathrm{kg} \mathrm{fed}^{-1}\right)$ in the two growing seasons.

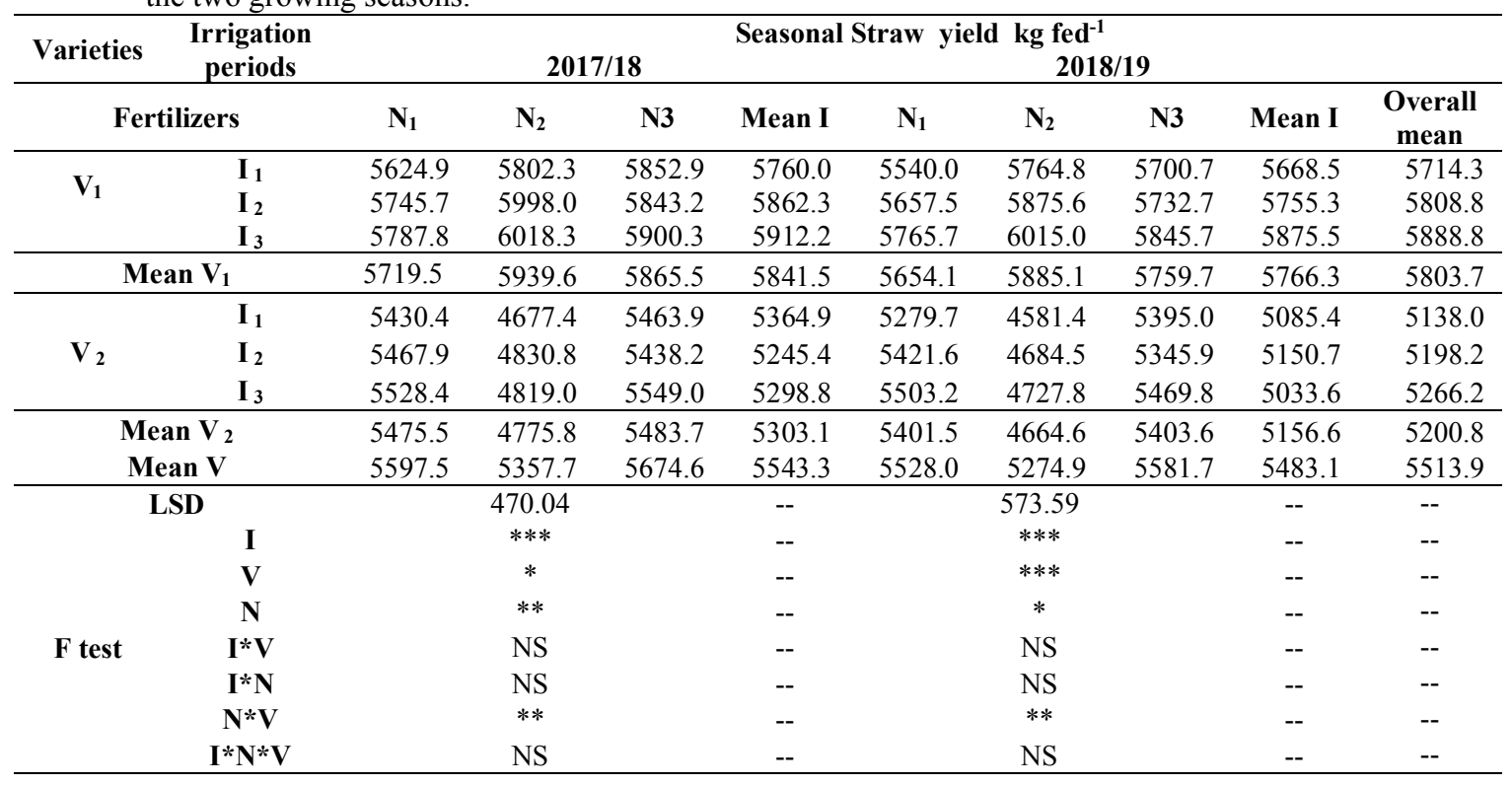
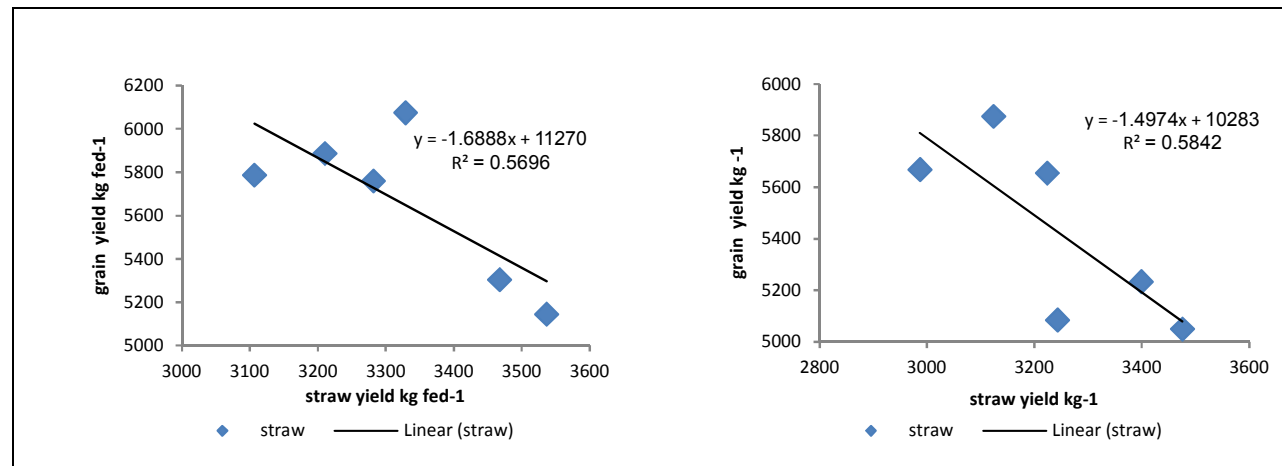

Fig 3: The relationship of grain wheat yield with straw wheat yield during two growing seasons.

\section{Some yield attributes}

\section{Plant height, cm}

Regarding irrigation periods, the highest values of wheat plant height 89.27 and $88.98 \mathrm{~cm}$ for Gemaza-11 and 90.76 and $90.08 \mathrm{~cm}$ for Misr-1 in the first and second growing seasons, respectively (Table 10), obtained from irrigation every 35 days, and the lowest values due to irrigation every 21 days with corresponding values in the second season are 87.82 and $87.36 \mathrm{~cm}$ for Gemaza-11 and 89.39 and $88.14 \mathrm{~cm}$ for Misr-1. This result is in harmony with the finding of Abdelkhalek et al. (2015) concluded that irrigation of wheat plants 5 irrigations till harvest led to significant increase and gave the highest values of plant height.

Concerning cultivar effect, the highest values were recorded under Misr-1 as compared with the values in Gemaza-11 in the two growing seasons. In addition, nitrogen doses have significant effect in this trait, the highest values were obtained under three doses application and the lowest values were due to one dose under overall irrigation periods and two varieties in the two growing seasons.

So, it could be concluded that plant length $(\mathrm{cm})$ is might be affected the basis of ranking; by irrigation periods, variety in the first season and nitrogen doses. Data in the same Table showed that, irrigation periods - variety interaction, irrigation periods - nitrogen doses interactions and irrigation periods - variety - nitrogen doses interaction did not significantly affect plant height for this study in both seasons. 
Table 10: Effect of irrigation intervals, nitrogen doses and wheat varieties on seasonal plant height, $\mathrm{cm}$ in the two growing seasons.

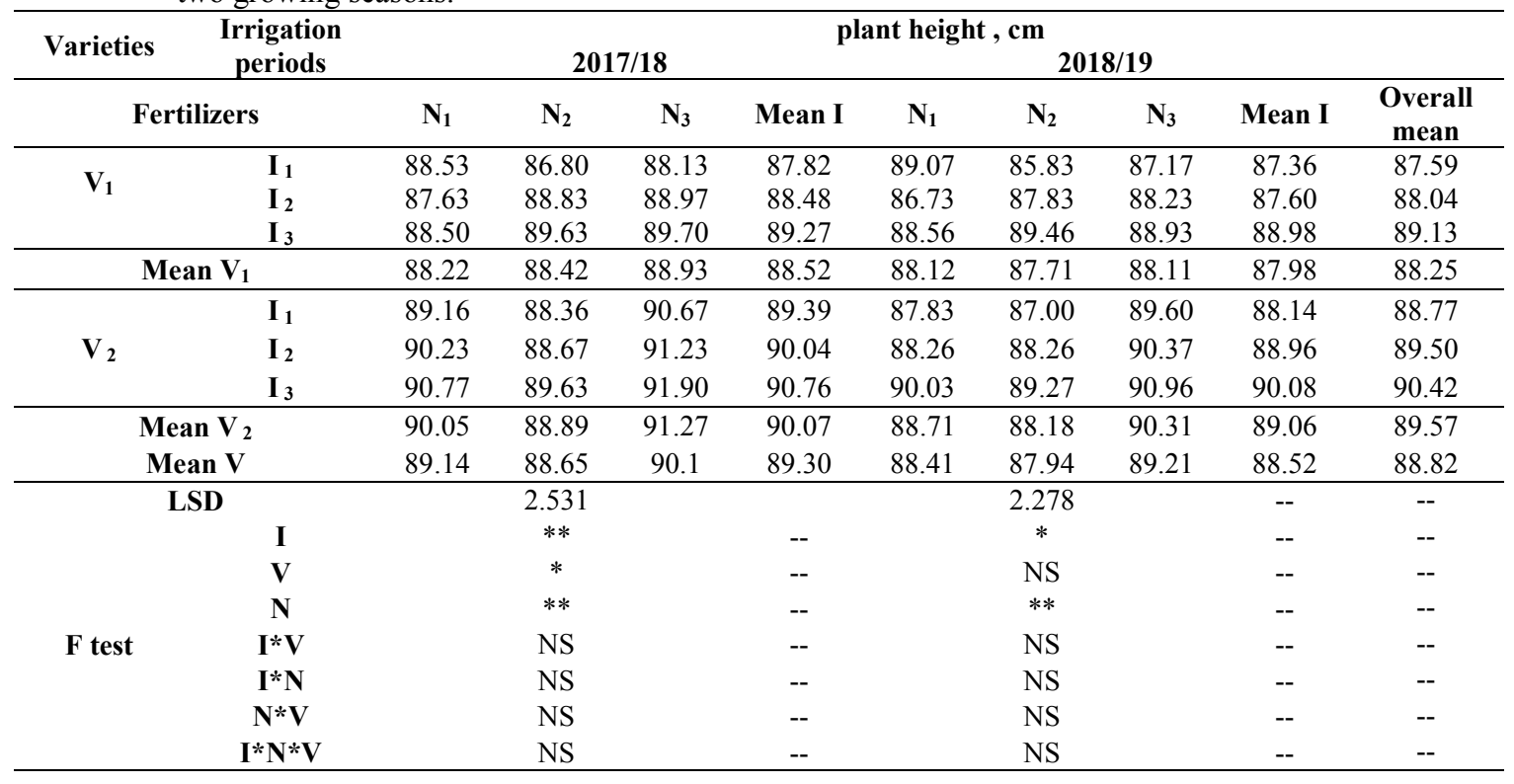

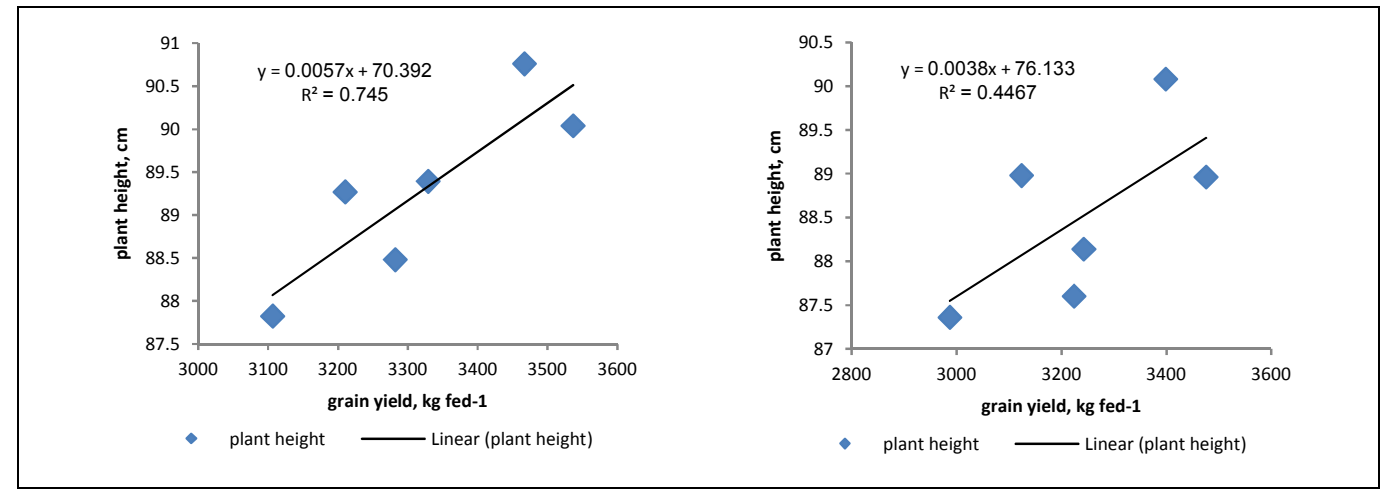

Fig. 4: The relationship of grain wheat yield with plant height, $\mathrm{cm}$ during two growing seasons.

\section{Spike length, $\mathrm{cm}$}

As shown in Table 11, values of spike length, $\mathrm{cm}$ was significantly affected by irrigation periods. In the first and second seasons, the highest values of spike length were obtained under irrigation every 35 days $\mathrm{I}_{3}$, and the lowest under irrigation every 21 days $\mathrm{I}_{1}$. Concerning variety effect, the highest value $(9.79 \mathrm{~cm})$ is recorded under Misr-1 and the lowest value $(9.21 \mathrm{~cm})$ is due to Gemaza-11. The corresponding values in the second season are 9.75 and $9.19 \mathrm{~cm}$. These results are agreement with the finding of Abdelkhalek et al. (2015)

In addition, nitrogen doses have significant effect in this trait, the highest values in the first season $(9.29$ and $9.91 \mathrm{~cm})$ is obtained under addition nitrogen in three doses $\left(\mathrm{N}_{3}\right)$ and the lowest value $(9.16$ and $9.67 \mathrm{~cm})$ are due to addition nitrogen in one dose $\left(\mathrm{N}_{1}\right)$ for Gemaza-11 and Misr-1, respectively. The corresponding values in the second season are $(9.23$ and $9.86 \mathrm{~cm})$ and $(9.19$ and 9.64 $\mathrm{cm})$.

So, it could be concluded that spike length $(\mathrm{cm})$ was affected on the basis of ranking; irrigation periods, variety, nitrogen doses and irrigation periods - variety interaction. Data in the same Table showed that, irrigation periods - nitrogen doses interaction and irrigation periods - variety - nitrogen doses interactions did not significantly affect spike length in both seasons. 
Table 11: Effect of irrigation intervals, nitrogen doses and wheat varieties on seasonal spike length, $\mathrm{cm}$ in the two growing seasons.

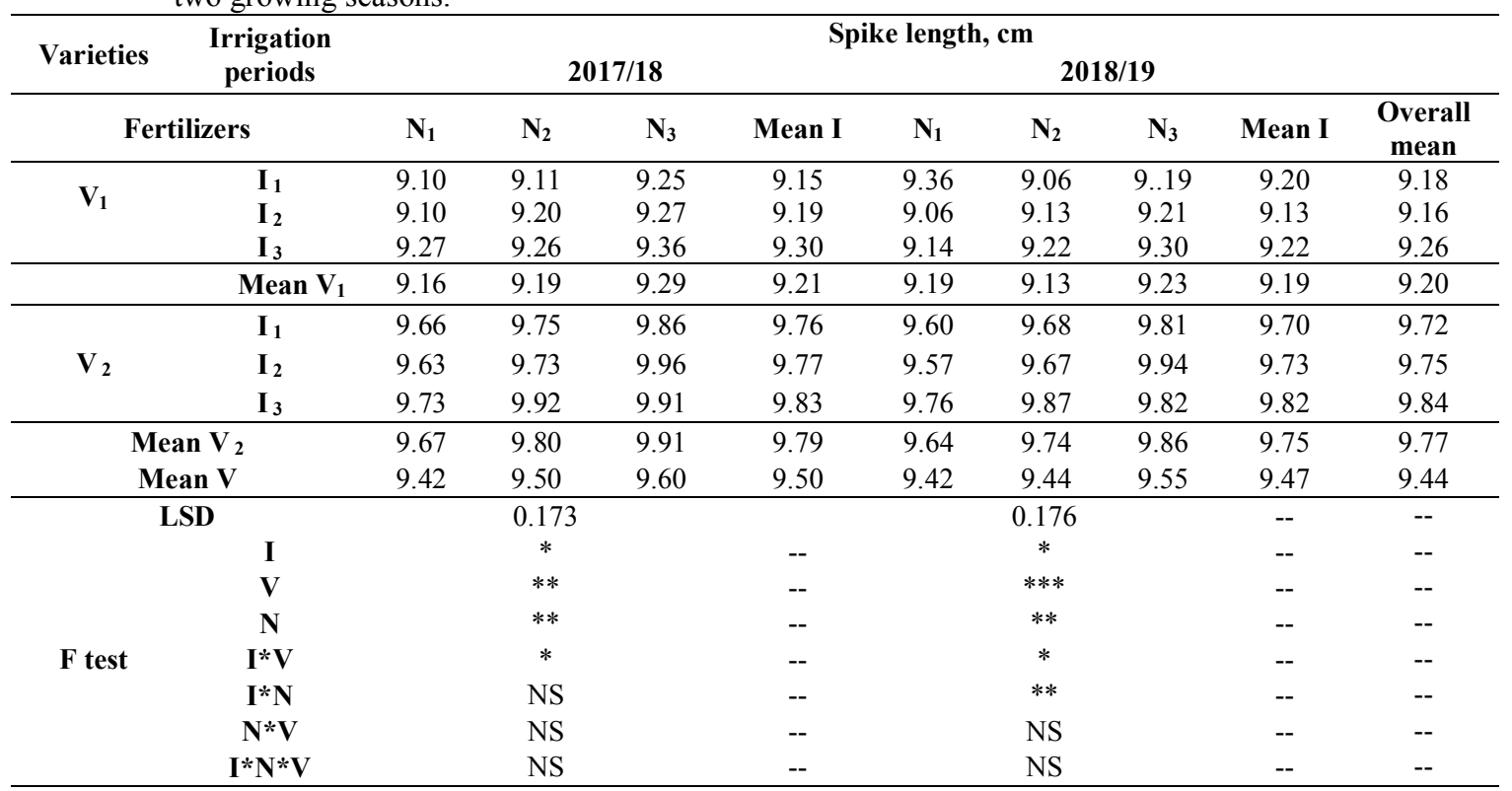
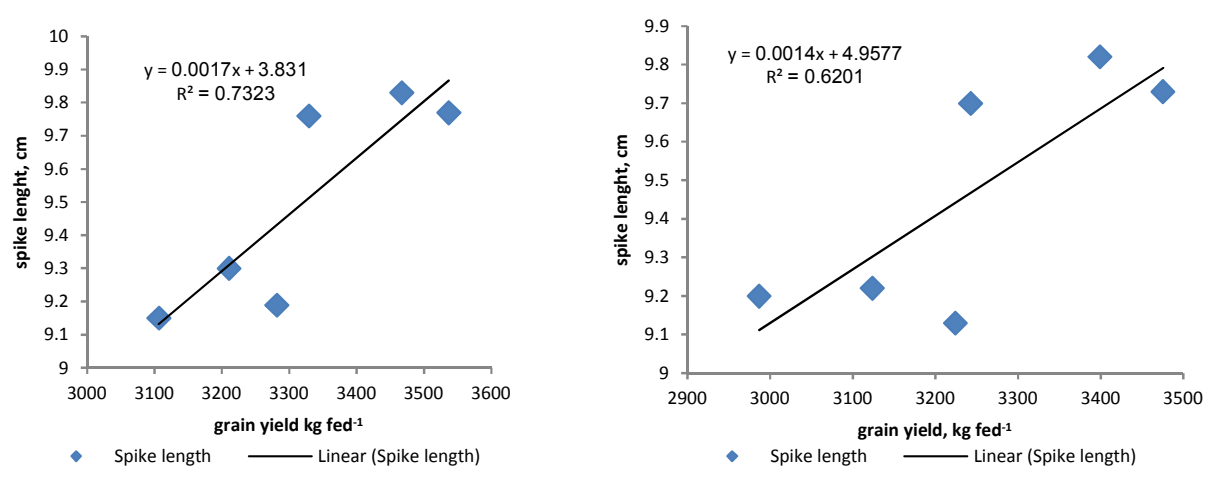

Fig 5: The relationship of grain wheat yield with spike length, $\mathrm{cm}$ during two growing seasons.

Number of spike, $\mathbf{m}^{-2}$

As shown in Table 12, values of spike number $\mathrm{m}^{-2}$, were affected by irrigation periods. In the overall seasons, the highest values of number of spike, $\mathrm{m}^{-2}$ (295.50 and 307.17 spike $\mathrm{m}^{-2}$ ) were obtained under irrigation every 35 days $\mathrm{I}_{3}$, and the lowest $\left(290.00\right.$ and 306.44 spike $\mathrm{m}^{-2}$ ) were due to irrigation every 21 days $I_{1}$ under Gemaza- 11 and Misr-1 respectively.

Concerning variety effect, the highest values were recorded also under Misr-1and the lowest numbers were attributed to Gemaza-11 in the two growing seasons.

In addition, nitrogen doses was has significantly effect on this trait, the highest values were obtained under three doses application and the lowest values were due to one dose under overall irrigation periods and two varieties in the two growing seasons. The previous results are in full agreement with those reported by Kamel- Nadia et al. (2007).

So, it could be noticed that number of spike, $\mathrm{m}^{-2}$ is might be affected the basis of ranking; irrigation periods, variety and nitrogen doses, with no effect among the interactions in the studied trait.

\section{0 grain weight, $\mathrm{gm}$}

Data of Table (13) indicated that Misr-1 produced highest values of 1000 grains weight under irrigation every 35 days $\mathrm{I}_{3}$ (28.9 and $27.6 \mathrm{~g}$ ) in the first and second seasons, respectively. On the other side Gemaza-11 under the irrigation every 21 day recorded the lowest values (38.71 and $37.78 \mathrm{~g}$ ) in both seasons, respectively. 
Table 12: Effect of irrigation intervals, nitrogen doses and wheat varieties on seasonal number of spike in the two growing seasons.

\begin{tabular}{|c|c|c|c|c|c|c|c|c|c|c|}
\hline \multirow{2}{*}{ Varieties } & \multirow{2}{*}{$\begin{array}{c}\text { Irrigation } \\
\text { periods }\end{array}$} & \multicolumn{9}{|c|}{ Number of Spike, $\mathbf{m}^{-2}$} \\
\hline & & \multicolumn{3}{|c|}{ 2017/18 } & \multicolumn{5}{|c|}{ 2018/19 } & \multirow[b]{2}{*}{$\begin{array}{c}\text { Overall } \\
\text { mean }\end{array}$} \\
\hline \multicolumn{2}{|c|}{ Fertilizers } & $\mathbf{N}_{1}$ & $\mathbf{N}_{2}$ & $\mathbf{N}_{3}$ & Mean I & $\mathbf{N}_{1}$ & $\mathbf{N}_{2}$ & $\mathbf{N}_{3}$ & Mean I & \\
\hline \multirow{3}{*}{$\mathbf{V}_{1}$} & $\mathbf{I}_{1}$ & 290.00 & 289.33 & 294.00 & 291.11 & 286.33 & 288.67 & 291.67 & 288.89 & 290.00 \\
\hline & $\mathbf{I}_{2}$ & 290.33 & 292.67 & 297.66 & 293.55 & 285.33 & 288.33 & 292.00 & 288.55 & 291.05 \\
\hline & $\mathbf{I}_{3}$ & 293.67 & 297.33 & 303.33 & 298.11 & 290.00 & 294.33 & 294.67 & 293.00 & 295.56 \\
\hline \multirow{3}{*}{$\mathbf{V}_{2}$} & $\mathbf{I}_{1}$ & 301.33 & 311.00 & 316.00 & 309.44 & 295.00 & 304.33 & 311.00 & 303.44 & 306.44 \\
\hline & $\mathbf{I}_{2}$ & 303.66 & 313.67 & 315.33 & 310.89 & 300.67 & 309.67 & 308.00 & 306.11 & 308.50 \\
\hline & $\mathbf{I}_{3}$ & 306.00 & 311.00 & 316.00 & 311.00 & 299.00 & 305.67 & 305.33 & 303.33 & 307.17 \\
\hline \multirow{2}{*}{\multicolumn{2}{|c|}{$\begin{array}{l}\text { Mean } V_{2} \\
\text { Mean V }\end{array}$}} & 303.66 & 311.89 & 315.78 & 310.44 & 298.22 & $306 . .56$ & 305.33 & 304.30 & 307.37 \\
\hline & & 297.50 & 302.50 & 307.05 & 302.35 & 292.72 & 298.50 & 300.45 & 299.77 & 299.79 \\
\hline \multirow{5}{*}{ F test } & $\mathbf{N}$ & & $* *$ & & -- & & $*$ & & -- & -- \\
\hline & $I * V$ & & NS & & -- & & NS & & -- & -- \\
\hline & $\mathbf{I} * \mathbf{N}$ & & NS & & -- & & NS & & -- & -- \\
\hline & $\mathbf{N} * \mathbf{V}$ & & NS & & -- & & NS & & -- & -- \\
\hline & $\mathbf{I} * \mathbf{N} * \mathbf{V}$ & & NS & & -- & & NS & & -- & -- \\
\hline
\end{tabular}
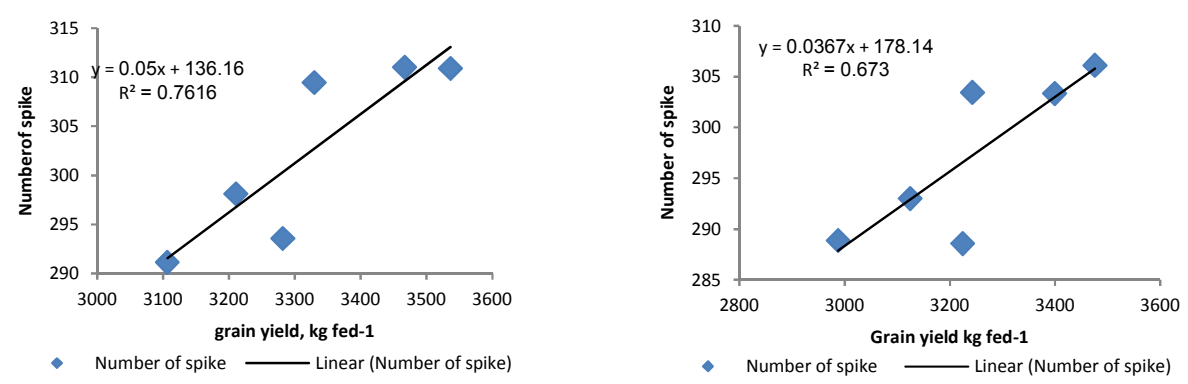

Fig. 6: The relationship of grain wheat yield with number of spike during two growing seasons.

Table 13: Effect of irrigation intervals, nitrogen doses and wheat varieties on seasonal weight of 1000 grain, gm in the two growing seasons.

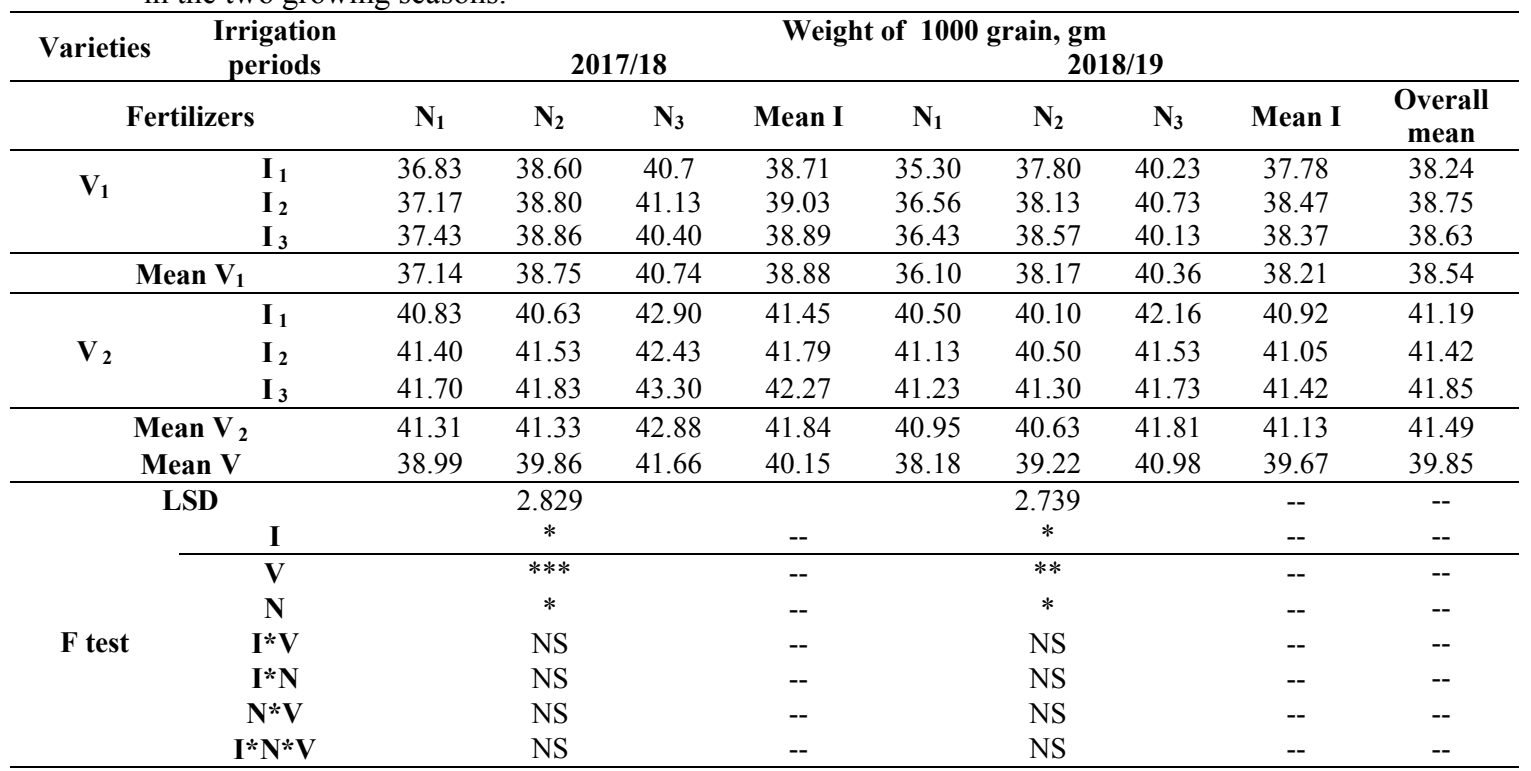




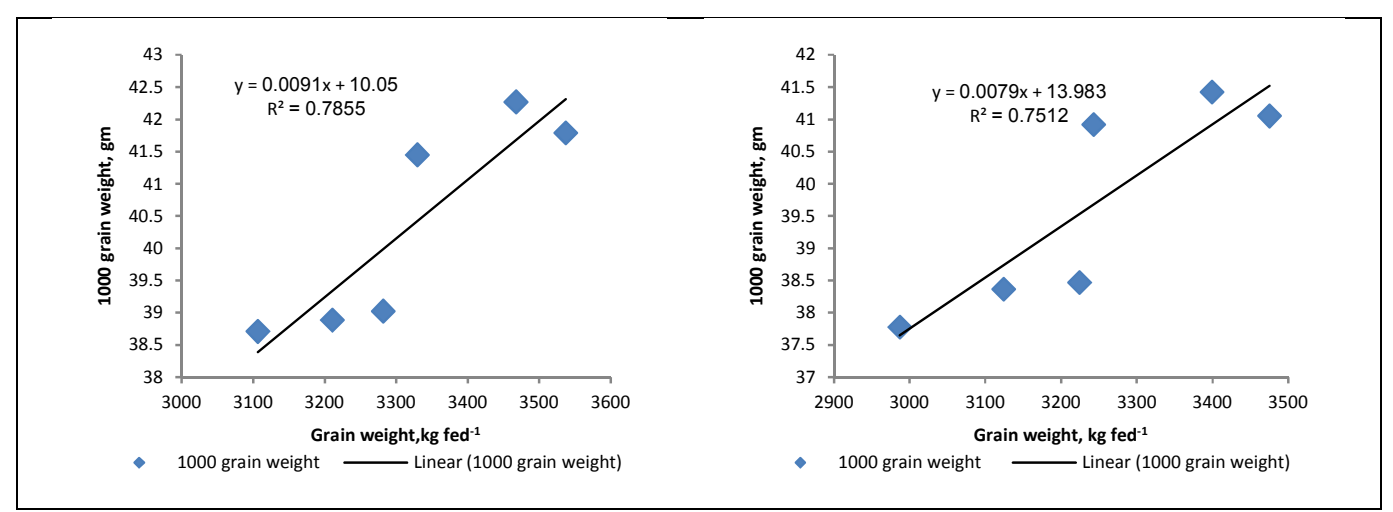

Fig. 7: The relationship of grain wheat yield with 1000 grain weight, gm during two growing seasons.

These results are in harmony with the finding of Abdelkhalek et al. (2015) they reported that, the irrigation treatments ( 3 events) gave the highest values for 1000 grain weight, gm.

Regarding the effect of the variety on 1000 grains weight, data presented in Table (13) reveal that treatment $\left(\mathrm{V}_{2}\right)$ gave the highest values, with significant decrease in Gemaza-11 in both seasons.

In addition, nitrogen doses was has significantly effect on this trait, the highest values were obtained under three doses application and the lowest values were due to one dose under overall irrigation periods and two varieties in the two growing seasons.

So, it could be stated that 1000 grain weight is might be affected by; irrigation periods, variety and nitrogen doses. Data of table (13) indicated that no significant effect on 1000 grains weight was in irrigation periods - variety interaction, irrigation periods - nitrogen doses and irrigation periods variety - nitrogen doses under this study in both seasons.

\section{Conclusion}

This current investigation recommended that, under the North Middle Nile Delta region, wheat crop (Misr-1 and Gemaza-11) should be irrigated every 35 days through the growing season, in addition application nitrogen fertilizer as three doses to obtained the best yield, yield attributes and maximization the values of water productivity.

\section{References}

Abd El-Hay, G.H., 2008. Effect of irrigation regimes and phosphate fertilizer rates on yield, yield components and water use efficiency of faba bean. Al-Azhar. J. Agric. Sci. Sector Res., 4: 125134.

Abdelkhalek, A.A., R. Kh. Darwesh and Mona A.M. El-Mansoury 2015. Response of some wheat varieties to irrigation and nitrogen fertilization using ammonia gas in North Nile Delta region. Annals of Agricultural Science (2015) 60(2), 245-256.

Abd el Raouf, R.E., S.F. El Habbasha, M. H. Taha, and K.M. Refaie, 2013. Effect of Irrigation Water Requirements and Fertigation Levels on Growth, Yield and Water Use Efficiency in Wheat Middle-East Journal of Scientific Research, 16 (4): 441-450.

Alam, M.S., M.N. Nesa, S.K. Khan, M.B. Hossain, and A. Hoque, 2007. Varietal Differences on Yield and Yield Contributing Characters of Wheat under Different Levels of Nitrogen and Planting Methods, J. Appl. Sci. Res., 3(11): 1388-1392.

Ali M.H., M.R. Hoque, A.A. Hassan and A. Khair, 2007. Effect of deficit irrigation on yield water productivity, and economic returns of wheat. Agric. Water Manag., 92(3): 151-161.

Ali, E.A., 2010. Grain yield and nitrogen use efficiency of pearl millet as affected by plant density, nitrogen rate and splitting in sandy soil. American-Eurasian J. Agri. Envi. Sci. 7(3): 327-335.

Ashraf, M., M.N. Asgher and M.N Saeed, 2001. Evaluation of alternate and regular furrows under skimmed groundwater application. J. Drain. Water Manage. 5, 13-22.

Doorenbos, J. and A. H. Kassam, 1979. Yield response to water. FAO. Irrigation and drainage paper 33, Rome, Italy. 
Doorenbos, J. and W.O. Pruitt, 1977. Guidelines for predicting crop water requirements. FAO Irrig. Drain. Pap. 24.

El-Sabbagh, S.A.; S.A. Abd El-Hafez; A.Z. El-Bably and E.I. Abou-Ahmed, 2002. Wheat productivity as influenced by soil moisture level sand foliar spray with some organic acids. Minufiya J. Agric. Res. 27(2): 425-438.

Gomez, K. A. and A. Gomez, 1984. Statistical procedures for agricultural research. 1sted. Johnwilley $\&$ sons. New York.

Hansen, J., T. Bond, B. Cairns, H. Gaeggler, B. Liepert, T. Novakov, and B. Schichtel, 2004. Carbonaceous aerosols in the industrial era. Eos Trans. Amer. Geophys. Union, 85, no. 25, 241, 245.

Hansen, V.W., Israelsen, D.W., Stringharm, D.E., 1979. Irrigation Principle and Practices, fourth ed. Johns Willey \&Sons, New York, USA.

Hefzy, M., 2015. Inter-relationship Between Modern Irrigation Systems and Fertilizers Application Methods. Ph.D Fac. Agric.,Assiut, Univ. Egypt.

Jackson M.L., 1973. Soil chemical analysis. Prentice Hall of India, Private Ltd. New Delhi, India.

James L.G. 1988. Principles of farm irrigation system design. John Willey and Sons Inc., New York, U.S.A. 543.

Kamel-Nadia, H., M.A. Youssef, M.N.A. Saeedn and Ibrahim, Seham A., 2007. Effect of hardening and water stress on growth, yield and anatomical features of wheat plants (Triticum aestivum L.). Egypt J. Appl. Sci., 22, 1-27.

Klute A. 1986. Water retention: laboratory methods: In: A . Koute (ed). Methods of soil analysis, Part $1,2^{\text {nd }}$ ed. Agron. Monoger. 9, ASA, Madison, WI, USA, pp. 635-660.

Mehrotra O.N., N.S. Sinha and R.D.L. Srivastava, 1967. Studies on nutrition of Indian cereals. I. Uptake of nitrogen by wheat plants at various stages of growth as influenced by phosphorus. Plant Soil 26:361-368.

Michael, A. M., 1978. Irrigation - Theory and practices. Vikas Publishing House, Delhi.

Moursi, E., R. M. Khalifa, A. M. Meleha, and M. A. Aiad, 2019. Effect of Irrigation Scheduling at Different Management Allowable Deficit Using Pan Evaporation on Wheat Yield and Water efficiencies at North Delta. J. Sus. Agric. Sci., 45(1): 11-25

Moursi, E.A. and R.Kh. Darwesh, 2014. Effect of Irrigation and Nitrogen Fertiziation on Sugar Beet Yield, Quality and Some Water Relations in Heavy Clay Soils. Alexandria Science Exchange Journal, Vol. 35, No.3, 234-248

Novica, V., 1979. Irrigation of agriculture crops. Fac. Agric. Press, Nvia sad, Yugoslavia.

Ouda, Samiha A., Abou, R. Elenin and M.A. Shreif 2010. Simulation of the effect of irrigation water saving on wheat yield at Middle Egypt. In: Fourteenth International Water Technology Conference, IWTC, Cairo, Egypt, pp. 407-419.

Parameswaran K. V. M., R. D. Graham, and D. Aspinall, 1981. Studies on the Nitrogen and Water Relations of Wheat, Irrig Sci., (1981) 3: 29-44.

Raj raj PalMeena, Venkatesh Karnam, S.C. Tripathi AnkitaJha, R.K. Sharma and G.P. Singh, 2019. Irrigation management strategies in wheat for efficient water use in the regions of depleting water resources. Agricultural Water Management (214): 38-46

Shaaban, S.M., 2006. Effect of organic and inorganic nitrogen fertilizer on wheat plant under water regime. Journal of Applied Sciences Research, 2: 650-656.

Shah, W.A., J. Bakht, T. Ullah, A. Khan, M. Zubair and A. Khakwani, 2006. Effect of sowing dates on the yield and yield components of different wheat varieties. Agron. J., 5(1): 106-110.

Sobh, M. M. 1997. Wheat response to nitrogen and $\mathrm{Zn}$ - application and different water regimes in northern Delta soils. Zagazig, J. Agric. Res. (5): 905-913.

Waller, R.A. and D.B. Duncan 1969. Symmetric multiple comparison problem. Amer. Stat. Assoc. Jour., pp1485- 1503 .

Wang, J., C. Xu, S. Gao, X. Han and Jü. D. Dangwei, 2013. Effects of Water and Nitrogen Utilized by Means of Dripping on Growth of Root and Canopy and Matter Distribution in Spring Wheat, Adv. J. Food. Sci. Technol., 5(4): 474-481. 